Supplement of The Cryosphere, 12, 1177-1194, 2018

https://doi.org/10.5194/tc-12-1177-2018-supplement

C Author(s) 2018. This work is distributed under

the Creative Commons Attribution 4.0 License.

(c) (1)

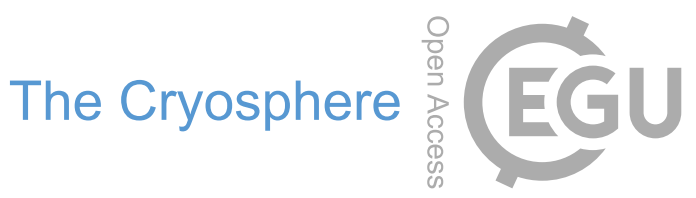

Supplement of

\title{
Nitrate deposition and preservation in the snowpack along a traverse from coast to the ice sheet summit (Dome A) in East Antarctica
}

\section{Guitao Shi et al.}

Correspondence to: Guitao Shi (gt_shi@163.com) and Meredith G. Hastings (meredith_hastings@brown.edu)

The copyright of individual parts of the supplement might differ from the CC BY 4.0 License. 
5 Table S1 Atmospheric concentrations of $\mathrm{NO}_{3}{ }^{-}$and $\mathrm{SO}_{4}{ }^{2-}$ on the traverse from coastal Zhongshan Station 6 to Dome A in East Antarctica.

\begin{tabular}{|c|c|c|c|c|c|}
\hline \multirow{2}{*}{$\begin{array}{c}\text { Sample } \\
\text { ID }\end{array}$} & \multirow[t]{2}{*}{ Sampling date } & \multicolumn{2}{|c|}{ Sampling location } & \multirow{2}{*}{$\begin{array}{c}\text { Atmospheric } \mathrm{NO}_{3}^{-} \\
/ \mathrm{ng} \mathrm{m}^{-3}\end{array}$} & \multirow{2}{*}{$\begin{array}{c}\text { Atmospheric } \mathrm{SO}_{4}{ }^{2} \\
/ \mathrm{ng} \mathrm{m}^{-3}\end{array}$} \\
\hline & & Longitude $/{ }^{\circ} \mathrm{E}$ & Latitude $/^{\circ} \mathrm{S}$ & & \\
\hline AN01 & 15-16, Dec., 2015 & 76.49 & 69.79 & 25 & 161 \\
\hline AN02 & 16-17, Dec., 2015 & 76.92 & 70.64 & 20 & 125 \\
\hline AN03 & 17-18, Dec., 2015 & 77.62 & 71.5 & 17 & 158 \\
\hline AN04 & 18-19, Dec., 2015 & 77.69 & 72.37 & 11 & 123 \\
\hline AN05 & 19-20, Dec., 2015 & 77.17 & 73.15 & 17 & 122 \\
\hline AN06 & 20-22, Dec., 2015 & 76.97 & 73.86 & 22 & 86 \\
\hline AN07 & 22-23, Dec., 2015 & 76.98 & 74.9 & 31 & 118 \\
\hline AN08 & 23-24, Dec., 2015 & 76.82 & 75.87 & 11 & 127 \\
\hline AN09 & 24-25, Dec., 2015 & 77.02 & 76.86 & 30 & 211 \\
\hline AN10 & 25-26, Dec., 2015 & 77.71 & 77.15 & 61 & 193 \\
\hline AN11 & 26-27, Dec., 2015 & 76.99 & 78.36 & 97 & 113 \\
\hline AN12 & 27-29, Dec., 2015 & 77.00 & 79.01 & 24 & 87 \\
\hline AN13 & 29-30, Dec., 2015 & 77.26 & 79.82 & 64 & 114 \\
\hline AN14 & 30-31, Dec., 2015 & 77.12 & 80.42 & 118 & 320 \\
\hline AN15 & 3-5, Jan., 2016 & 77.12 & 80.42 & 43 & 238 \\
\hline AN16 & 10-12, Jan., 2016 & 77.12 & 80.42 & 57 & 220 \\
\hline AN17 & 12-14, Jan., 2016 & 77.12 & 80.42 & 65 & 201 \\
\hline AN18 & 14-16, Jan., 2016 & 77.12 & 80.42 & 80 & 268 \\
\hline AN19 & 16-18, Jan., 2016 & 77.12 & 80.42 & 80 & 205 \\
\hline AN20 & 18-19, Jan., 2016 & 77.12 & 80.42 & 52 & 155 \\
\hline AN21 & 19-20, Jan., 2016 & 77.12 & 80.42 & 56 & 115 \\
\hline AN22 & 21-22, Jan., 2016 & 77.17 & 79.63 & 55 & 152 \\
\hline AN23 & 22-23, Jan., 2016 & 77.03 & 78.77 & 14 & 170 \\
\hline AN24 & 23-24, Jan., 2016 & 77.19 & 77.83 & 27 & 185 \\
\hline AN25 & 24-25, Jan., 2016 & 77.02 & 76.74 & 24 & 191 \\
\hline AN26 & 25-26, Jan., 2016 & 77.03 & 76.42 & 30 & 244 \\
\hline AN27 & 26-27, Jan., 2016 & 76.83 & 75.87 & 30 & 183 \\
\hline AN28 & 27-28, Jan., 2016 & 76.96 & 75.03 & 33 & 189 \\
\hline AN29 & 28-29, Jan., 2016 & 77.00 & 74.09 & 24 & 162 \\
\hline AN30 & 29, Jan.-1, Feb., 2016 & 76.97 & 73.86 & 16 & 152 \\
\hline AN31 & 1-2, Feb., 2016 & 77.38 & 72.84 & 13 & 170 \\
\hline AN32 & 2-3, Feb., 2016 & 77.97 & 71.93 & 6 & 172 \\
\hline AN33 & 3-4, Feb., 2016 & 77.19 & 70.97 & 19 & 169 \\
\hline AN34 & 4-6, Feb., 2016 & 76.52 & 69.97 & 12 & 168 \\
\hline
\end{tabular}




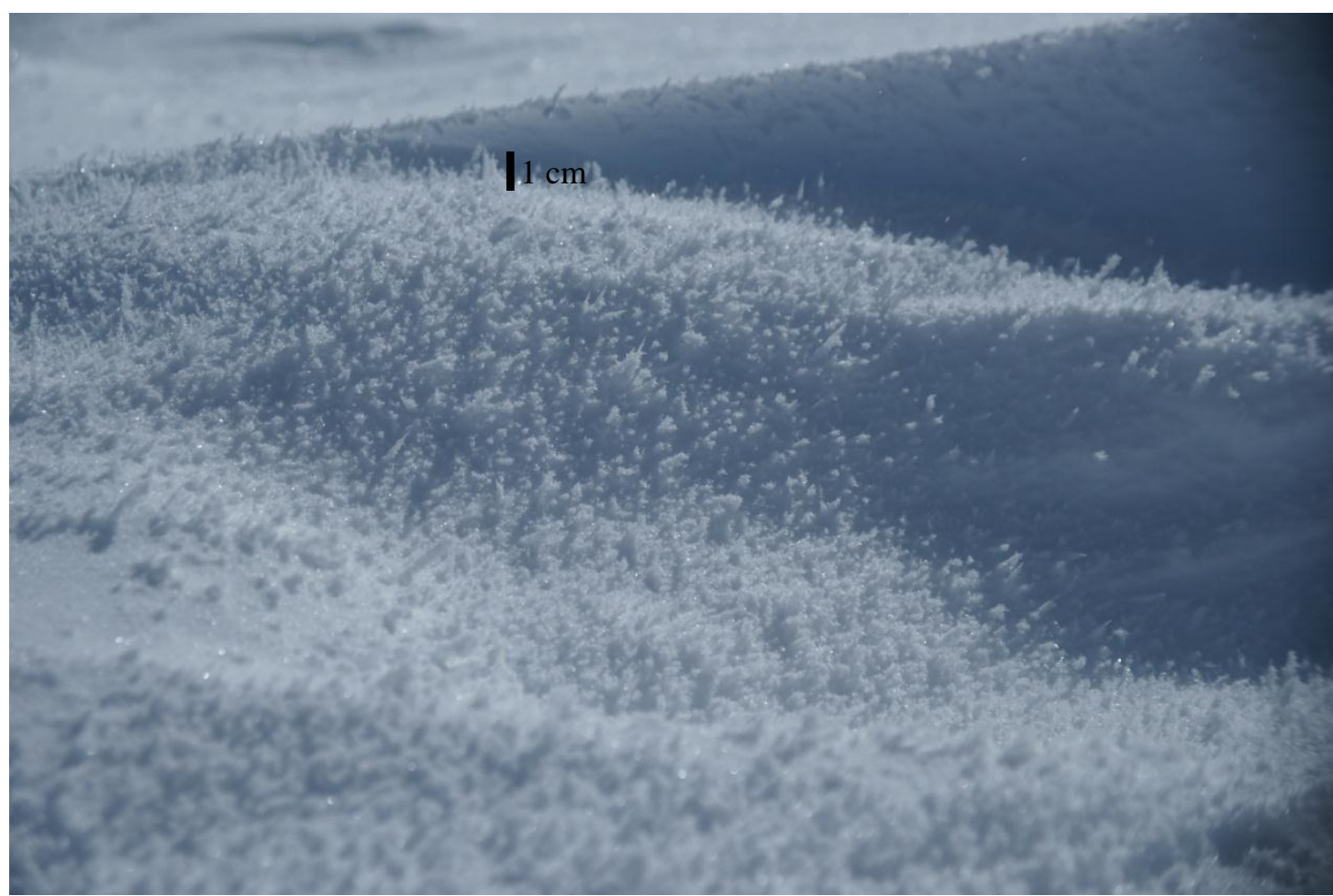

Figure S1 Surface morphology of the snow on Dome A plateau, East Antarctica. The needle crystal ice layer is extensively developed. In general, the depth of the crystal layer is $<1.0 \mathrm{~cm}$, and the snowpack is characterized by soft snow texture. 

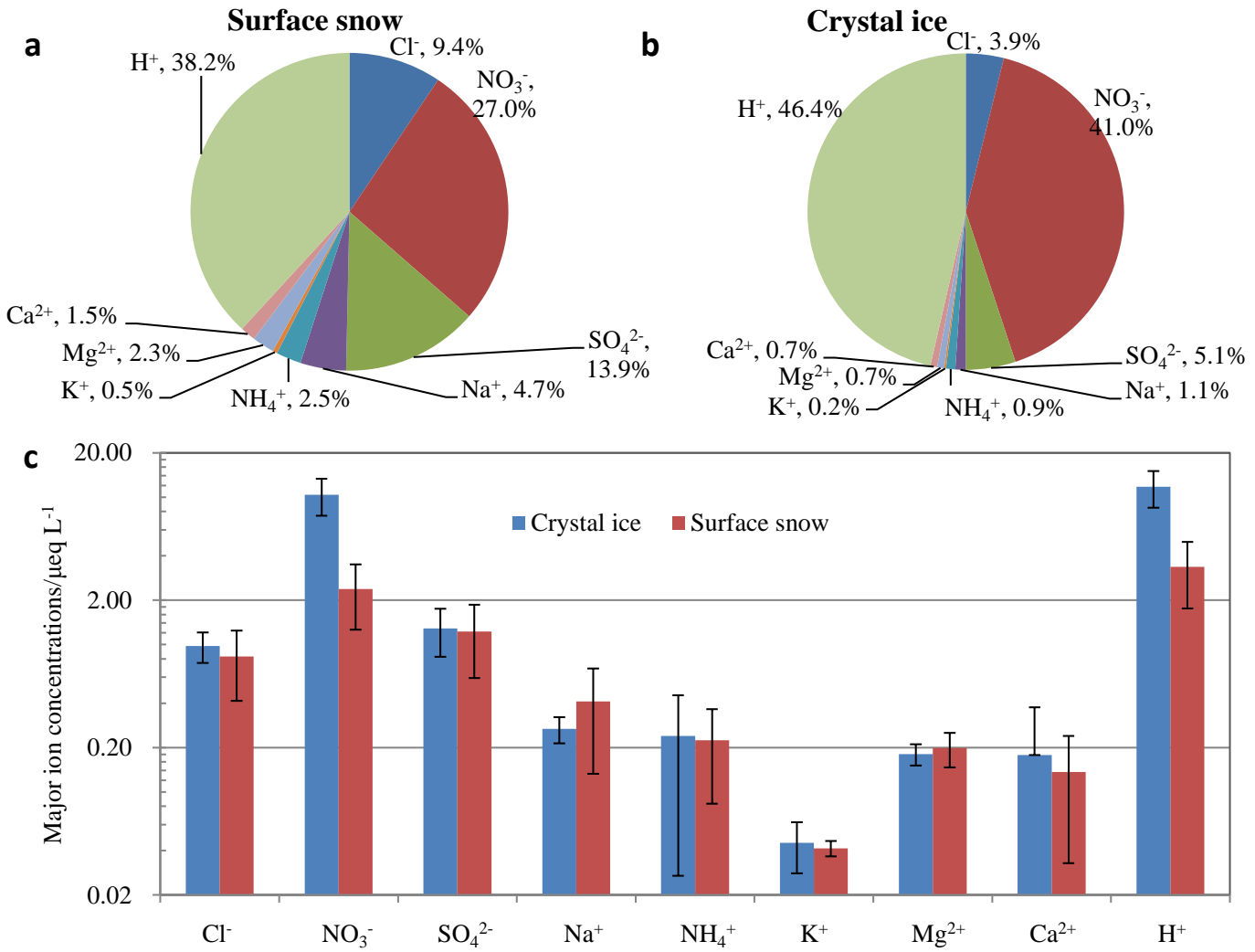

Figure S2 Major chemical ions in surface snow and crystal ice samples on the traverse from coast to the ice sheet summit (Dome A) in East Antarctica. Contribution percentages of each ion to total ion concentrations are shown in (a) and (b), respectively. Concentrations of ions in surface snow and crystal ice are shown in (c), with error bars of one standard deviation $(1 \sigma)$. The concentration of $\mathrm{H}^{+}$is calculated from the difference between sum anions and sum cations. Note that a base-10 log scale is used for ion concentrations in (c). 


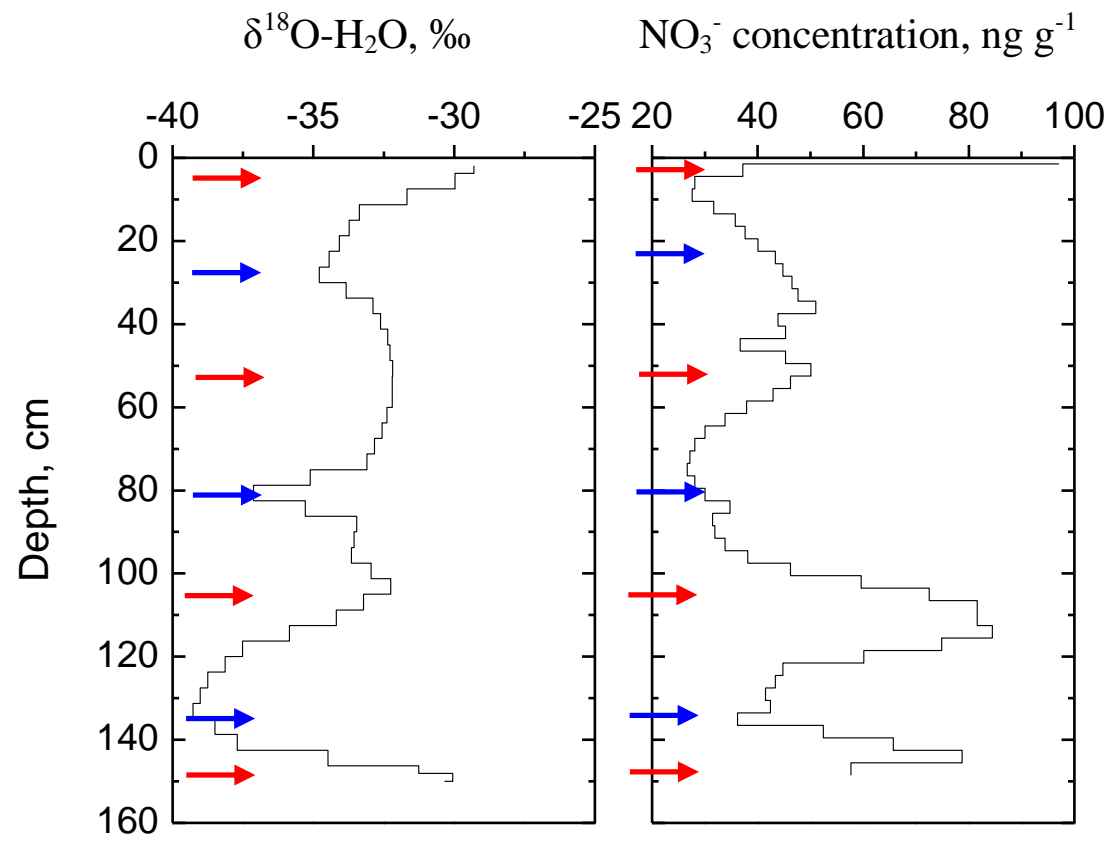

22

23 Figure $\mathrm{S} 3$ Profiles of $\delta^{18} \mathrm{O}$ of $\mathrm{H}_{2} \mathrm{O}$ (left panel) and $\mathrm{NO}_{3}{ }^{-}$concentration (right panel) in the coastal snowpit SP2. Red and blue arrows represent the middle of the identified warm and cold seasons, respectively. Red solid arrows and blue dashed arrows represent the middle of the identified warm and cold seasons, respectively. One seasonal cycle represents one $\delta^{18} \mathrm{O}\left(\mathrm{H}_{2} \mathrm{O}\right)$ local maxima peak to the next. 


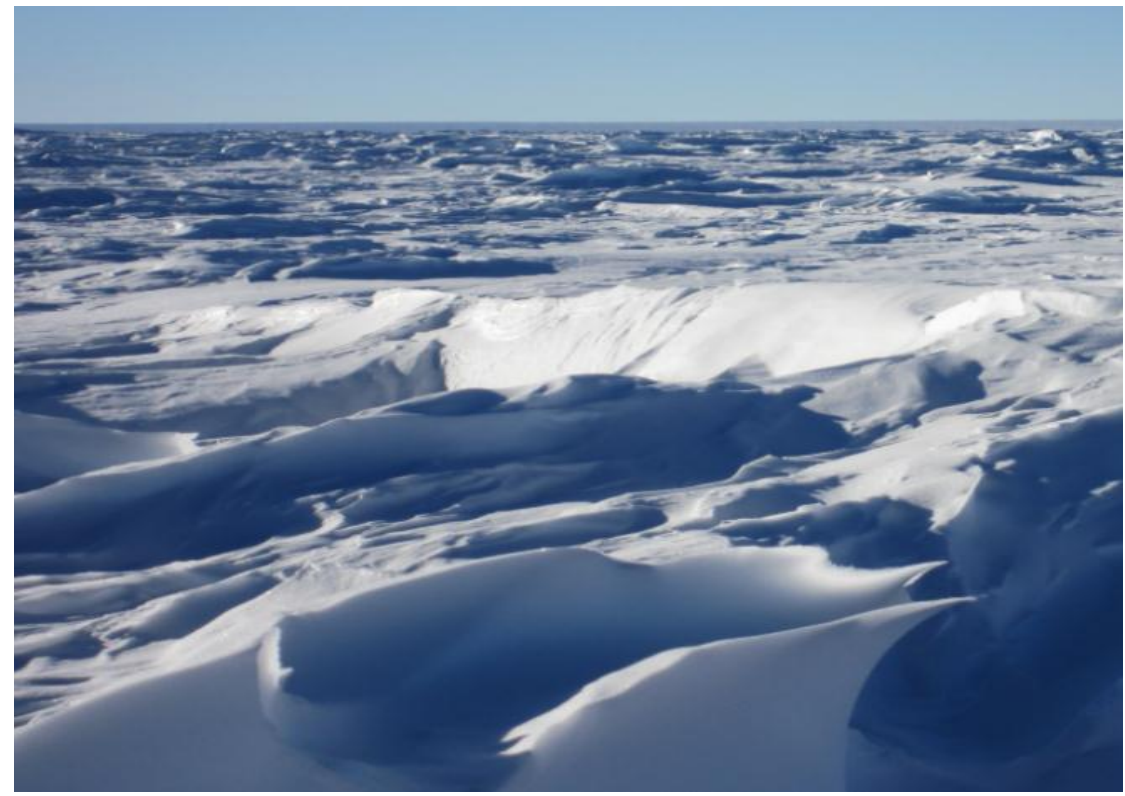

30

31

32

33

34

35

Figure S4 Surface morphology of the surface snow at $\sim 600 \mathrm{~km}$ from the coast, on the traverse from Zhongshan to Dome A, East Antarctica. The large sastrugi with hard smooth surfaces is extensively developed in this region, mainly formed by wind erosion. The ridges of these sastrugi are typically parallel to the prevailing wind direction. 


\section{References}

Erbland, J., Vicars, W., Savarino, J., Morin, S., Frey, M., Frosini, D., Vince, E., and Martins, J.: Air-snow transfer of nitrate on the East Antarctic Plateau - Part 1: Isotopic evidence for a photolytically driven dynamic equilibrium in summer, Atmos. Chem. Phys., 13, 6403-6419, doi:10.5194/acp-13-6403-2013, 2013.

Frey, M.M., Savarino, J., Morin, S., Erbland, J., and Martins, J.: Photolysis imprint in the nitrate stable isotope signal in snow and atmosphere of East Antarctica and implications for reactive nitrogen cycling, Atmos. Chem. Phys., 9, 8681-8696, 2009.

Savarino, J., Kaiser, J., Morin, S., Sigman, D.M., and Thiemens, M.H.: Nitrogen and oxygen isotopic constraints on the origin of atmospheric nitrate in coastal Antarctica, Atmos. Chem. Phys., 7, 1925-1945, 2007.

Shi, G., Li, Y., Jiang, S., An, C., Ma, H., Sun, B., and Wang, Y.: Large-scale spatial variability of major ions in the atmospheric wet deposition along the China Antarctica transect $\left(31^{\circ} \mathrm{N}^{\sim} 69^{\circ} \mathrm{S}\right)$, Tellus $\mathrm{B}, 64$, 17134, doi:10.3402/tellusb.v64i0.17134, 2012.

Zatko, M.C., Geng, L., Alexander, B., Sofen, E.D., and Klein, K.: The impact of snow nitrate photolysis on boundary layer chemistry and the recycling and redistribution of reactive nitrogen across Antarctica and Greenland in a global chemical transport model, Atmos. Chem. Phys., 16, 2819-2842, doi:10.5194/acp-16-2819-2016, 2016. 